$$
\text { УДК 336.025: } 657.6
$$

https://doi.org/10.32689/2618-0065-2020-3(5)-101-109

Кравченко Юлія Петрівна, кандидат економічних наук, доцент кафедри державного управління у сфері цивільного захисту Інституту державного управління та наукових досліджень 3 цивільного захисту, моб. тел. (097) 96445 39, e-mail: kravchenko-yulia@ukr.net, https: //orcid.org/0000-0002-3709-7016

\title{
ВНУТРІШНІЙ КОНТРОЛЬ - АТРИБУТ ЕФЕКТИВНОГО УПРАВЛІННЯ БЮДЖЕТНОЮ УСТАНОВОЮ ДЕРЖАВНОЇ СЛУЖБИ УКРАЇНИ 3 НАДЗВИЧАЙНИХ СИТУАЦІЙ
}

Анотація. Одним із завдань сталого розвитку суспільства $\epsilon$ децентралізація управління в державному секторі, тобто делегування повноважень щодо прийняття управлінських рішень центральними органами виконавчої влади на місця. Реалізація децентралізованого управління можлива завдяки належним чином організованому внутрішньому контролі. Адже, зазначений контроль надає впевненість головним розпорядникам бюджетних коштів, що всі прийняті управлінські рішення на місцях $\epsilon$ обгрунтованими та виваженими. Крім того, в сучасних умовах функціонування бюджетних установ 3 обмеженими ресурсами постає важливе завдання 3 пошуку можливих шляхів заощадження таких ресурсів та ефективного їх використання.

У статті відзначено, що організація системи внутрішнього контролю в бюджетній установі сприятиме прийняттю економічно обгрунтованих, результативних, ефективних управлінських рішень 3 дотриманням вимог чинного законодавства щодо використання матеріальних, фінансових чи інших ресурсів бюджетної установи, які є обмеженими. Автором досліджено походження терміну «внутрішній контроль» та наявні у міжнародній практиці моделі внутрішнього контролю. Порівняння моделей COSO та COSO ERM зображено графічно. Стаття відображає коротку історію запровадження системи внутрішнього контролю у нормативно-правових актах України. Також даний науковий доробок містить розкриті питання організації внутрішнього контрою безпосередньо в бюджетній установі 3 особливим місцем ідентифікації та оцінки ризиків в даному процесі. Зазначено важливість організації та забезпечення належного рівня функціонування внутрішнього контролю бюджетними установами системи Державної служби України з надзвичайних ситуацій, адже на них покладено функції з питань цивільного захисту. Вплив внутрішнього контролю на 
ефективність управління бюджетною установою проілюстровано в статті графічно.

Ключові слова: внутрішній контроль, бюджетна установа, управлінські рішення, управління бюджетною установою, ефективність, результативність, економічність, система Державної служби України 3 надзвичайних ситуацій.

Kravchenko Yuliia Petrovna, $\mathrm{PhD}$ in Economics, Associate Professor of the Department of Public Administration in the sphere of civil protection, Institute of Public Administration in the Sphere of Civil Protection, моб. тел. (097) 96445 39, e-mail: kravchenko-yulia@ukr.net, https: //orcid.org/0000-0002-3709-7016

\section{INTERNAL CONTROL - AN ATTRIBUTE OF EFFECTIVE BUDGETARY INSTITUTION'S MANAGEMENT}

Abstract. Decentralization of management in the public sector is one of the internationally defined tasks of sustainable development of society. Decentralization of management involves the delegation of powers to make management decisions by central executive bodies to the local level. Implementation of decentralized management will be possible due to properly organized internal control. This control provides assurance to the main managers of budget funds that field management decisions are reasonable and balanced. In addition, search for possible ways of saving resources and efficient use them is an important task for the functioning of budgetary institutions with limited resources in modern conditions.

The article notes, that the organization of the internal control system in the budgetary institution will ensure the adoption of economically sound, effective, efficient management decisions in compliance with current legislation on the use of limited material, financial or other resources of the budgetary institution. The author researched the origin of the term "internal control" and the existing international models of internal control. Comparison of internal control models are depicted graphically. A brief history of the internal control system's introduction in the legislation of Ukraine is revealed in the article. Issues of organization of internal control in the budgetary institution are also disclosed in this scientific work. A special place in the internal control system is occupied by the identification and risk assessment. The organization of internal control and ensuring the proper level of its functioning by budgetary institutions of the system of The State Emergency Service of Ukraine is an important author's accent. After all, such budgetary institutions perform socially important functions on civil protection issues. The impact of internal control on the effectiveness of budgetary institution's management is illustrated graphically in the article.

Keywords: internal control, budgetary institution, management decisions, budgetary institution's management, efficiency, effectiveness, economically, the system of The State Emergency Service of Ukraine. 
Постановка проблеми. Трансформаційні процеси, які огортають всі сфери діяльності в Україні у зв'язку 3 імплементацією у ці сфери європейських практик, вимагають перебудови укорінених підходів та оперативного реагування на нові виклики. Не стала виключенням й вітчизняна система державного управління, оскільки вона $\epsilon$ важливим показником конкурентоспроможності держави.

3 метою визначення ключових напрямів реформування державного управління Урядом України схвалено Стратегію реформування державного управління України на період до 2021 року[1]. У 2018 році експерти Програми підтримки вдосконалення врядування та менеджменту (SIGMA) провели оцінку стану державного управління, яку відобразили у Звіті про базові вимірювання «Принципи державного управління», а Рахункова палата - аудит комплексної реформи державного управління, за результатами яких 3 урахуванням накопиченого досвіду та консультацій із заінтересованими сторонами цю Стратегію оновлено [2]. Крім того, згідно звіту SIGMA однією 3 короткострокових рекомендацій (1-2 роки) за результатами огляду підзвітності визначено поширення Урядом культури децентралізованого управління в міністерствах, використовуючи делегування повноважень щодо прийняття рішень від державних секретарів до керівників департаменту, залишаючи при цьому за державними секретарями загальну відповідальність за систему внутрішнього контролю в міністерстві [2].

Реалізація децентралізованого управління можлива завдяки належним чином організованому внутрішньому контролі, який здатен забезпечити прийняття ефективних стратегічних управлінських рішень на підставі повної та достовірної інформації, виключаючи вплив суб'єктивних факторів. Саме тому важливо досліджувати систему внутрішнього контролю, визначаючи недоліки ï функціонування в центральних органах виконавчої влади i обласних державних адміністраціях й можливі шляхи удосконалення.

Аналіз останніх досліджень і публікацій. Теорію та методологію державного управління досліджували Ю. В. Ковбасюк, К. О. Ващенко, Ю. П. Сурмін та ін. [3]. Питання контролю, як способу забезпечення законності і дисципліни у сфері державного управління, зокрема контролю 3 боку центральних органів виконавчої влади висвітлені в науково-методичних доробках В. І. Загуменника, В. В. Проценко [4]. Ян ван Тайнен, Андрєєв П.П., Чечуліна О. О., Тимохін М. Г. та інші у спільній науково-методичній праці висвітлили особливості побудови системи внутрішнього контролю на рівні міністерства/установи [5].

Вищезгадані науковці досліджували здебільшого відокремлено або державне управління, або ж внутрішній контроль, в окремих випадках поверхнево згадуючи про те, що контроль $є$ інструментом державного управління. Віддаючи належне представленим працям, питання впливу внутрішнього контролю на ефективність державного управління залишається малодослідженим, що тягне за собою ігнорування та формальну організацію в організаціях/установах внутрішнього контролю. Це пояснює важливість 
дослідження як системи внутрішнього контролю, так i iï впливу на ефективність управління організацією/установою зокрема та на ефективність державного управління в цілому..

Виклад основного матеріалу. Міжнародною організацією вищих органів фінансового контролю (INTOSAI) розроблено Керівництво по стандартам внутрішнього контролю для державного сектора - додаткова інформація з управління ризиками організації (INTOSAI GOV 9130). Згідно даного керівництва, внутрішній контроль - це цілісний процес, який здійснюється керівництвом та персоналом суб'єкта господарювання та спрямований на подолання ризиків та надання належної впевненості у досягненні цілей діяльності суб'єкта господарювання, зокрема: здійснення регламентованих, етичних, економічних, продуктивних та ефективних операцій; виконання зобов'язань 3 підзвітності; дотримання чинного законодавства та правил; захист ресурсів від втрат, нераціонального використання та збитків [6].

Від початку міжнародні стандарти рекомендували розбудовувати внутрішній контроль в організаціях державного сектору на базі п’яти компонентів: контрольне середовище, оцінка ризику, контрольна діяльність, інформація та комунікація, моніторинг. Дана модель системи внутрішнього контролю є найпростішою та має назву модель COSO або COSO I. Назва їі походить від абревіатури COSO, яка $\epsilon$ скороченою назвою Комітету спонсорських організацій Комісії Тредвея, який вперше сформував спрощену модель системи внутрішнього контролю для корпоративного сектору, яку адаптували до державного сектору.

Згодом, у зв'язку із низкою подій, які відбулися на міжнародній фінансовій арені й торкнулися аудиторських фірм виникла необхідність перегляду системи корпоративного управління. Як наслідок, в 2004 році Комітет спонсорських організацій Комісії Тредвея опублікував Концептуальні основи управління ризиками організації, в якій основою провадження внутрішнього контролю стала модель COSO ERM (Enterprise Risk Management - Управління ризиками підприємства).

Тому Керівництво по стандартам внутрішнього контролю для державного сектора - додаткова інформація 3 управління ризиками організації (INTOSAI GOV 9130) передбачає побудову системи внутрішнього контролю на підставі моделі COSO ERM, що грунтується на методиці ризикменеджменту. Відмінність моделі COSO та COSO ERM подано на рис. 1.

Першоджерелом, яке регламентувало необхідність побудови п’яти елементної системи внутрішнього контролю на базі моделі COSO в державному секторі в Україні була Концепція розвитку державного внутрішнього фінансового контролю на період до 2017 року. 3 метою створення єдиного правового поля для розвитку даної системи було внесено зміни до ст. 26 Бюджетного кодексу України від 08.07.2010 № 2456-VI, визначивши поняття внутрішнього контролю та внутрішнього аудиту. Відтак внутрішній контроль є комплексом заходів, що застосовуються керівником для забезпечення дотримання законності та ефективності використання 
бюджетних коштів, досягнення результатів відповідно до встановленої мети, завдань, планів і вимог щодо діяльності розпорядника бюджетних коштів i підприємств, установ та організацій, що належать до сфери його управління [7].

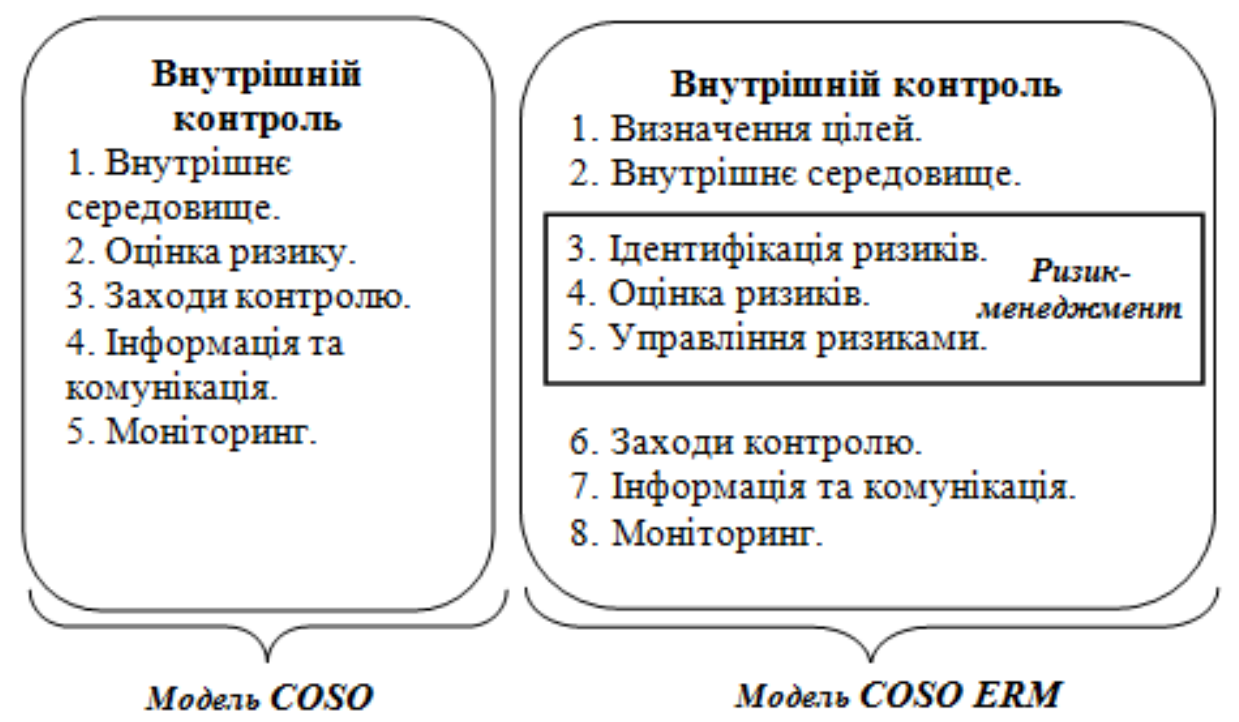
відмінності

Рис. 1. Моделі внутрішнього контролю COSO та COSO ERM, їх

Оскільки поняття внутрішнього контролю для державного сектору України було новим виникла необхідність в методичних вказівках, які б роз'яснили процес впровадження такого контролю в бюджетних установах. Тому наказом Міністерства фінансів України від 14.09.2012 № 995 було затверджено Методичні рекомендації з організації внутрішнього контролю розпорядниками бюджетних коштів у своїх закладах та у підвідомчих бюджетних установах. Проте їх рекомендаційний характер дав можливість керівникам установ формально запроваджувати внутрішній контроль, тобто без чіткого дотримання положень згаданих методичних рекомендацій.

Пряме зобов'язання керівників розпорядників бюджетних коштів 3 організації внутрішнього контролю в державному секторі виникло 3 прийняттям Основних засадах здійснення внутрішнього контролю розпорядниками бюджетних коштів, затверджених постановою Кабінету Міністрів України від 12.12.2018 № 1062.

На виконання вищевказаних нормативно-правових актів Державною службою України 3 надзвичайних ситуацій (далі - ДСНС), як відповідальним виконавцем бюджетних програм, наказом від 20.02.2019 № 112 затверджено Порядок з організації внутрішнього контролю в системі ДСНС. Дія даного порядку поширюється на всі підвідомчі ДСНС установи та організації, тому перед ними стоїть завдання не лише організувати внутрішній контроль, а й забезпечити належний рівень його фактичного функціонування. Порядком внутрішній контроль визначено, як комплекс заходів, що застосовуються керівником для забезпечення дотримання законності та ефективності використання бюджетних коштів, досягнення 
результатів відповідно до встановленої мети, завдань, планів і вимог щодо діяльності бюджетної установи та iï підвідомчих установ [8].

В даному визначенні прослідковується прямий вплив внутрішнього контролю на законність, ефективність, економічність та результативність діяльності бюджетної установи, що складається із системи прийнятих управлінських рішень. Під законністю розуміється чітке дотримання норм законодавства України під час проведення будь-яких операцій в межах бюджетної установи. Поняття ефективності визначається як співвідношення між отриманими результатами від прийняття управлінського рішення та використаними ресурсами. Результативність - в якій мірі досягнуто поставлені цілі, очікувані результати діяльності бюджетної установи. Категорію економічності характеризує осягнення очікуваних результатів від прийняття управлінського рішення із використанням мінімальних ресурсів належної якості.

Дослідимо, яким же чином організувати внутрішній контроль в бюджетній установі, щоб досягти виконання зазначених вище результативних категорій діяльності установи. Розпочати необхідно саме 3 визначення відповідальної особи (робочої групи) в бюджетній установі за організацію внутрішнього контролю. Базовою компонентою розбудови внутрішнього контролю в організації $є$ відповідне нормативно-правове забезпечення, а саме порядок організації внутрішнього контролю із відображенням всіх напрямів діяльності установи (зазвичай у вигляді функцій із статуту чи іншого основного документу, який регламентує діяльність бюджетної установи) та відповідальних за напрямами. Відповідальні особи за встановленими напрямами визначають ключові процеси та розробляють адміністративні регламенти на підставі яких здійснюватимуться заходи внутрішнього контролю.

Наступним кроком є ідентифікація та оцінка ризиків здійснення визначених процесів. Ризик - це ймовірність настання негативних подій або ненастання бажаних подій, що може вплинути на прийняття окремих управлінських рішень та діяльність установи загалом. Зважаючи на зазначене, визначати перелік ризиків потрібно надзвичайно ретельно. Оцінка ідентифікованих ризиків здійснюється із застосуванням Матриці оцінки ризиків, а результати документуються. Кожен із ідентифікованих та оцінених ризиків відноситься до певного виду ризиків в межах зовнішніх (законодавчі, операційно-технологічні, програмно-технічні) або внутрішніх (нормативно-правові, операційно-технологічні, програмно-технічні, кадрові, фінансово-господарські). Відповідно оціненому рівню впливу ризику обирається адекватний захід контролю, який здатний нейтралізувати, або мінімізувати ймовірність реалізації ризику. Такий захід знаходить своє відображення у Плані з реалізації заходів контролю, моніторингу та впровадження їх результатів, який приймається на рік. Крім того, в Плані зазначаються очікувані результати від впровадження заходів контролю та заходи моніторингу. Таким чином, всі п'ять компонентів системи 
внутрішнього контролю бюджетної організації відображаються у вищеописаних внутрішніх нормативно-правових документах.

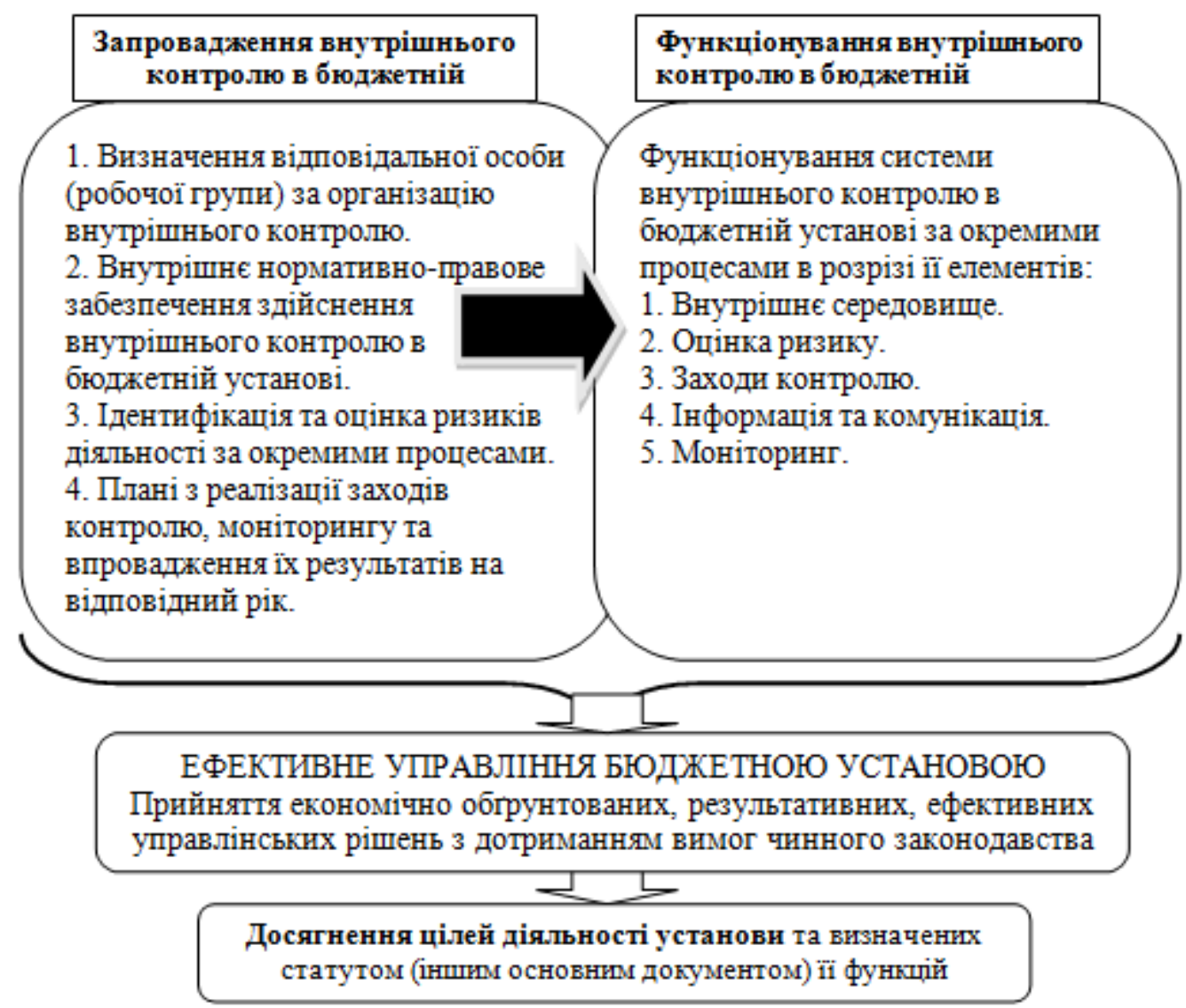

Рис. 2. Вплив внутрішнього контролю на ефективність управління бюджетною установою

3 моменту завершення організації внутрішнього контролю виникає відповідальне завдання для керівників всіх рівнів щодо постійного дотримання та виконання задекларованих норм. Як працює на практиці система внутрішнього контролю? Щоденно кожен працівник згідно посадових обов'язків (визначених посадовою інструкцією) бере участь у здійсненні певних операцій, які спрямовані на виконання процесів (передбачених положенням про відповідний структурний підрозділ) i забезпечують реалізацію бюджетною установою визначеної функції іiі діяльності. Заходи контролю, наприклад процедура візування документів, підтвердження, нагляд тощо, дають змогу уникнути помилок та інших порушень на стадії виконання операції. А оцінка ризиків вимагатиме посилених заходів контролю для операцій $з$ підвищеним ризиком і цим самим знизить можливість проведення даної операції 3 порушеннями законодавства.

Вплив належним чином організованого внутрішнього контролю на ефективність управління бюджетною установою відображено на рис. 2.

Висновки та перспективи подальших досліджень. Отже, запровадження внутрішнього контролю в бюджетних установах $є$ запорукою 
прийняття економічно обгрунтованих, результативних, ефективних управлінських рішень 3 дотриманням вимог чинного законодавства. Особливо важливо, щоб всі бюджетні установи системи ДСНС організували та забезпечили належний рівень функціонування внутрішнього контролю, адже наявність внутрішнього контролю не лише підвищить ефективність управління організацією, а й забезпечить виконання покладених на неї функцій $з$ питань цивільного захисту. Тобто матиме соціальний ефект, який вплине на добробут населення України в частині їх цивільного захисту.

Проте, однією з основних перепон на шляху реалізації представленого на рисунку впливу може стати формальність внутрішнього контролю, яка викликана недостатнім рівнем знань працівників системи ДСНС та обмеженим обсягом інформації з цих питань. Задля нейтралізації даної перепони необхідно враховувати в програмах навчання керівного складу та фахівців у сфері цивільного захисту питання запровадження та особливостей функціонування внутрішнього контролю в структурних підрозділах ДСНС України.

\section{Лimepamypa:}

1. Деякі питання реформування державного управління України: розпорядження Кабінету Міністрів України «» від 24.06.2016 № 474-p. URL: https://cutt.ly/Tap9dFT(дата звернення: 20.05.2020)

2. Принципи державного управління: звіт про базові вимірювання. Програма SIGMA. червень 2018 p. URL: https://cutt.ly/Sap9BID (дата звернення: 20.05.2020).

3. Державне управління: підручник: у 2 т. /Ю. В. Ковбасюкта ін. К.; Дніпропетровськ: НАДУ, 2012. Т. 1. 564 с.

4. Загуменник В.I., Проценко В.В. Державне управління та виконавча влада в Україні: навч. посіб. Бендери: Поліграфіст Київ, 2015. 295 с.

5. Державний внутрішній фінансовий контроль: Україна та Європейський Союз: навч. посіб. / ЯнванТайнен,URL: https://cutt.ly/Bap3BbO (дата звернення: 20.05.2020).

6. Guidelines for Internal Control Standards for the Public Sector 9130. International Organisation of Supreme Audit Institutions. URL: https://cutt.ly/jap8I9d (дата звернення: 20.05.2020).

7. Бюджетний кодекс України: Закон України від 08.07.2010 № 2456-VI. // База даних «Законодавство України». / BP України. URL: https://zakon.rada.gov.ua/laws/show/2456-17 (дата звернення 20.05.2020).

8. Про затвердження Порядку з організації внутрішнього контролю в системі ДСНС: наказ Державної служби України з надзвичайних ситуацій від 20.02.2019 №112. URL: https://ips.ligazakon.net/document/FN051079 (дата звернення: 20.05.2020).

\section{References:}

1. Rozporyadzhennya Kabinetu Ministriv Ukrayiny "Deyaki pytannya reformuvannya derzhavnogo upravlinnya Ukrayiny” vid 24.06.2016 № 474-r. [Order of the Cabinet of Ministers of Ukraine "Some issues of public administration reform in Ukraine" from june $\begin{array}{llllll}24, & 2016 & \text { № 474-r] } & \text { (n.d.). } & \text { zakon.rada.gov.ua Retrieved from }\end{array}$ https://zakon.rada.gov.ua/laws/show/ru/474-2016$\% \mathrm{D} 1 \% 80$ ?find= $1 \&$ lang=ru\&text=\%E2\%ED $\% \mathrm{~F} 3 \% \mathrm{~F} 2 \% \mathrm{~F} 0$ [in Ukrainian]. 
2. Pryncypy derzhavnogo upravlinnya: zvit pro bazovi vymiryuvannya. - Programa SIGMA. - cherven` 2018 r. [Principles of public administration: report on basic measurements: Programa SIGMA from june, 2018] www.kmu.gov.ua Retrieved from https://www.kmu.gov.ua/ua/diyalnist/reformi/efektivne-vryaduvannya/reforma-derzhavnogoupravlinnya [in Ukrainian].

3. Kovbasyuk, Yu.V., Vashchenko, K.O. \& Surmin, Yu.P. (Ed.). (2012). Derzhavne upravlinnya [Public administration] (Vols. 1-2). Dnipropetrovs`k: NADU. [in Ukrainian].

4. Zagumennyk, V.I. \& Procenko, V.V. (2015). Derzhavne upravlinnya ta vykonavcha vlada v Ukrayini [Public administration and executive power in Ukraine] Krupcan O.D. (Ed.). Kyiv: Bendery: Poligrafist. [in Ukrainian].

5. Yan van Tajnen, Andreyev, P.P., Chechulina, O.O., \& Tymoxin, M.G. ta in. (2011). Derzhavnyj vnutrishnij finansovyj kontrol`: Ukrayina ta Yevropejs`kyi Soyuz [Public internal financial control: Ukraine and the European Union] dkrs.kmu.gov.ua Retrieved from http://dkrs.kmu.gov.ua/kru/doccatalog/document?id=134078. [in Ukrainian].

6. Guidelines for Internal Control Standards for the Public Sector 9130. International Organisation of Supreme Audit Institutions. (n.d.). ms.hmb.gov.tr Retrieved from https://ms.hmb.gov.tr/uploads/2019/06/6883-

A22DF8F253B907C7599ED7639A374C05765D2DC7.pdf. [in English] .

7. Byudzhetnyj kodeks Ukrayiny vid 08.07.2010 № 2456-VI [Budget Code of Ukraine from July 08, 2010 № 2456-VI]. (n.d.). zakon.rada.gov.ua Retrieved from https://zakon.rada.gov.ua/laws/show/2456-17. [in Ukrainian].

8. Nakaz Derzhavnoyi sluzhby Ukrayiny $\mathrm{z}$ nadzvychajnyx sytuacij "Pro zatverdzhennya Poryadku z organizaciyi vnutrishn ogo kontrolyu v systemi DSNS" vid 20.02.2019 № 112. [Order of The State Emergency Service of Ukraine "On approval the Orderliness on the organization of internal control in the SESU's system from February 20, 2019 № $\quad$ 112]. $\quad$ (n.d.). ips.ligazakon.net Retrieved from https://ips.ligazakon.net/document/FN051079. [in Ukrainian]. 